\title{
LOS CARDENALES «PAPABLES» DEL SACRO COLEGIO Y LA PROBLEMÁTICA DE LOS CONCLAVES EN UN INFORME A D. JOSÉ DE CARVAJAL (1750)
}

\author{
José F. ALCARAZ GÓMEZ
}

\begin{abstract}
Resumen
Fueron frecuentes los informes confidenciales que responsables diplomáticos acreditados ante la Santa Sede remitieron a sus respectivas Cortes sobre el perfil personal y «político» de los distintos purpurados que componían el Colegio Cardenalicio. Su finalidad era contar con información pertinente con vistas a actuar con conocimiento de causa cuando falleciera el Pontífice y los cardenales tuvieran que elegir nuevo Papa, que se deseaba fuera proclive a colaborar con los intereses de la Corona. Se presenta aquí el redactado en 1750 , durante el pontificado de Benedicto XIV, por el auditor del tribunal de la Rota Alfonso Clemente de Aróstegui, posteriormente Consejero de Castilla y embajador español en Nápoles.
\end{abstract}

\begin{abstract}
The confidential reports that responsible diplomatics accredited before the Papal Seat transmitted to their respective Courts about the personal profile and «political» of the different cardinals that were composing the College of Cardinals were frequent. Their purpose was to count on relevant information and to act coherently and in the interest of the crown when the time come to choose a new pope. It is presented here the document of 1750 , during the reign of Benedicto XIV, by the auditor of the court of La Rota Clemente Alfonso de Aróstegui, later to the time counselor of Castille and Spanish ambassador in Napoles.
\end{abstract}

Dentro del trasiego de despachos que se cursaron en el Antiguo Régimen entre el gobierno de Madrid y su legación diplomática acreditada ante la Santa Sede -que recordemos que era doble, por un lado el embajador o ministro representaba al monarca católico ante el soberano de los Estados pontificios, y por otro el agente general de preces o peticiones que representaba al monarca ante el Sumo Pontífice de la Iglesia católica ${ }^{-}$- un puesto importante lo ocupan por derecho propio los informes cuasi

1. Sobre este aspecto, cf. OLAECHEA, R., S.I. Las relaciones hispano-romanas en la segunda mitad del XVIII. La agencia de preces. Zaragoza. (1965). t. I. p. 3 y ss.; y del mismo autor «Relaciones entre Igle- 
«policiales» que se remitían de vez en cuando sobre los cardenales comúnmente denominados «papables», que eran clasificados habitualmente como "sospechosos», «adictos» o «indiferentes». Como es sabido, en el año 1179 el pontífice Alejandro III, en el III Concilio de Letrán, decretó que la elección del Papa se hiciera única y exclusivamente por el Colegio de Cardenales, sin distinción alguna entre ellos, y que se considerase como Papa legítimo el que obtuviera las dos terceras partes de los votos. Las ritualidades de la elección fueron precisadas por disposiciones posteriores de diversos pontífices como Gregorio X (1274), Clemente V (1311), Clemente VI (1354), Julio II (1505), Pío IV (1562), Gregorio XV (1610), Urbano VIII (1626) y Clemente XII (1731). Por otra parte, Sixto V, por las constituciones Postquam Verus (1586) y Religiosa sanctorum (1587) fijó en 70 el número de plazas de cardenales del Sacro Colegio -medida que ha perdurado hasta tiempos recientes-, que casi nunca estaban ocupadas en su totalidad y que estaban divididas en tres clases u órdenes: 6 cardenales-obispos, 50 cardenales-presbíteros y 14 cardenales-diáconos. Envueltos como estaban los purpurados en la vida fastuosa de sus palacios entre una densa capa de intrigas, ambiciones y calculadas simulaciones que encubrían sus verdaderas personalidades mientras presentaban públicamente otras, la redacción de un informe como el que ahora presentamos entrañaba para los ministros españoles en Roma bastantes problemas. Pero dado que los diversos asuntos políticos, económicos, jurisdiccionales y disciplinares que se ventilaban entre ambas cortes eran de una gran gravedad, había que dar alguna orientación a Madrid, por subjetiva o imprecisa que fuese, sobre la constitución del Sacro Colegio a fin de que se pudiese trazar la política más adecuada en el caso de un hipotético cónclave. Esto era fundamental con vistas a buscar el acuerdo con otros Estados católicos -como se hizo en el siglo XVIII con las cortes borbónicas de Francia, Nápoles o Parma- y para que se pudiese elegir por compromiso al sujeto que se considerase más idóneo para la salvaguarda de los intereses dinásticos y para que ocupase la sede vacante de Pedro. Sabido es que un Papa favorable podría evitar muchos disgustos a la corte española y facilitar las demandas tanto espirituales como temporales que se le presentasen.

Por supuesto, el candidato siempre había de ser un cardenal italiano «papable», ya que los cardenales nacionales o de «coronas», promovidos al capelo por complacencia del pontífice de turno a las presiones de los gobiernos de Austria, España, Francia y Portugal, eran poco numerosos, parciales e inhábiles por propia definición al llevar la "exclusiva in ventre», según Aróstegui.

El autor del documento que reproducimos es Alfonso Clemente de Aróstegui (1698-1774), antiguo colegial de San Ildefonso de Alcalá, oidor de la audiencia de Zaragoza (1739-1744), después del tribunal de la Rota por la corona de Castilla (1744-1749) y encargado interinamente de los asuntos de España en Roma de mayo de 1747 -tras la muerte en marzo de aquel mismo año del cardenal embajador Troiano Acquaviva de Aragón - a noviembre de 1748 en que fue nombrado nuevo embajador el cardenal Joaquín Fernández Portocarrero por intervención del poderoso Padre Rávago, confesor real. Aunque Carvajal protegió a Aróstegui, éste fue acusado de haberse vendido a los romanos y no contó con las simpatías de Ensenada, si bien este

sia y Estado en el siglo de las Luces» en ALBEROLA, A. y LA PARRA, E. La llustración Española. Actas del coloquio internacional celebrado en Alicante. 1-4 octubre 1985. Alicante. (1986). pp. 271-297. 
célebre ministro lo tuvo siempre por «hombre de honor» ${ }^{2}$. En el verano de 1750 fue reemplazado en la auditoría por Manuel Ventura Figueroa, futuro artífice del Concordato de 1753. Así mismo, Aróstegui fue consejero del Consejo de Castilla (1749) y luego ministro de España en Nápoles (1753-1770), consejero de Estado (1759) y finalmente comisario general de Cruzada (1770). Durante los años que estuvo en Roma, además de informar atentamente a Madrid sobre las repercusiones que tenían en la corte pontificia asuntos tan graves como la controversia sobre el Patronato, la real cédula de Felipe V de 2 de septiembre de 1745 contra las coadjutorías de futura sucesión en los beneficios eclesiásticos o la controversia entre las Inquisiciones española y romana sobre las obras del cardenal agustino Noris, fue el principal artífice de una proyectada Academia de Historia eclesiástica que fue un fiasco y que hemos tratado en otro lugar. Además propuso infructuosamente a los titulares sucesivos de la $\mathrm{Se}$ cretaría de Estado - primero Villarias y luego Carvajal- la unión de la agencia de preces con una de las auditorías de la Rota ${ }^{+}$.

¿Cuáles fueron las motivaciones que movieron a Aróstegui a escribir este informe sobre los cónclaves que remitió la Secretaría de Estado en los meses previos a su salida de Roma y cuando el Papa reinante, Benedicto XIV (1740-1758) gozaba de buena salud? En carta de oficio a Carvajal, fechada en Roma el 19 de marzo de 1750, el interesado lo justificaba así: «es común opinión en Roma que el negocio más arduo y que pide mayor habilidad en un Ministro Regio sea la contingencia de un cónclave. Créese que el conseguir una corona una elección de Papa a su gusto, sea un objeto muy interesante. Créese también poderse llegar a este fin por el medio de negociaciones y manexos y en esta persuasión no ay Ministro que no prepare a su corte para el gran caso de la vacante del Pontificado, noticiando y sugiriendo quanto le pa-

2. Cf. nuestro estudio Jesuitas y reformismo. El Padre Francisco de Rávago (1747-1755). Prólogo de Antonio Mestre. Valencia. (1995), p. 474. n. 95.

3. Cf. Ibid. pp. 574-580.

4. «Dige a Vm. en el antecedente algo del Agente y en resumen es que no ai tal hombre en Roma y ahora digo para el caso que se pensase en hacer mutación que el Agente del Rey en Roma no tiene más por su empleo que solicitar los despachos que se consideran tocantes al Rey y su Patronato en estas oficinas $\mathrm{Pa}$ pales, lo que éste executa por medio de un expedicionero, con lo que se está quieto en su casa sin cuidarse de más por su genio y por no oponerse al Palacio de España al que profesa una total resignación. Además de lo dicho, solían aquí darse a los Agentes del Rey algunas comisiones e instrucciones para lo ocurrente al Real servicio, como se dieron a Arze y Cornejo, y aí constará si a éste se Je encargó algo. Lo cierto es que Arze y Cornejo tubieron por estos encargos lances bien pesados con los Ministros de su tiempo. Este goza la quietud que corresponde a su inacción resignada. Oi estamos en los términos de haverse dignado el Rey fiar a mí los encargos que V.S. sabe. Si éstos se han se seguir, conviene (mientras io no lo heche a perder), que la dirección aquí sea enteramente mía y que no haiga quien me desaiude siéndome contrario, o por parcialidad o por ambición, por lo que sería un gran ierro embiar aquí uno que engreído de su empleo o aparcializado [sic] con los mal contentos de mi conducta, me estorbase y enrredase. En cuio caso mejor estamos con quien no hace nada por la regla de nullius entis. Pero si como es razón se atiende a no dar un sueldo en vano y que de esta inación pueden originarse descuidos perjudiciales, y que io debo trabajar los encargos consabidos en el modo conveniente antes dicho; y así mismo que Io señalado con lo de la Rota apenas alcanzara para mi manutención, me parece sería una cosa justa que la Agencia con sus utilidades recaiese o se refundiese en mí por modo de una agregación absoluta, o si parecía, interina, o lo que importaba lo mismo». Aróstegui a Villarias. Confidencial. Roma, 30 de septiembre de 1745. A.G.S. Estado. Leg. 5104. En este mismo sentido se manifestó Aróstegui cuatro años después: «A la verdad que este empleo [el de agente de preces] se debiera suprimir por inútil y fuera bueno agregar su cuidado (que no es otro que tratar de las expediciones) a uno de los Auditores de Rota». Aróstegui a Carvajal. Confidencial. Roma, 20 de febrero de 1749. A.G.S. Estado. Leg. 4949. 
rece conduce al expresado fin. Movido de esta práctica y de la que han tenido hasta aquí los Ministros de España, juzgué de mi obligación en el tiempo que la piedad del Rey me confió sus negocios en esta corte aplicar yo también mi atención, ordenando mis discursos y mi tal qual parecer según las presentes circunstancias. Con efecto ha cerca de un año que formé el papel adjunto que no remití antes a V.E. por esperar ponerlo en sus manos y ahora remito en derechura por evitar contingencias del camino. Por muchas razones debo sujetarle a la sabia censura de V.E. y suplicarle instántemente lo retenga para sí, tanto más quanto reconozco que mis discursos, por desviarse en mucho de la opinión común, pueden ser menos aceptados, pues en el presente estado de cosas no creo que el suceso del cónclave pueda ser para España de la importancia que se dice, ni quando lo fuera se puede fundar esperanza provable en las negociaciones y manexos anticipados sobre el gran riesgo que corren éstos en la esquela de la conciencia. Por fin se pudiera casi decir que el Rey en semejante materia podía deponer toda solicitud a excepción de aquella que bastase a mostrar al Mundo que S.M. como Rey Cathólico deseava se diese a la Iglesia universal el Pastor más digno; lo que bastava a dar por su parte la authoridad y esplendor correspondiente a un acto tan solemne y se huía al mismo tiempo, como es justo, del estremo de manifestar menos aprecio del interés común de la Santa Iglesia. Yo celebraré que este trabajo enquentre la aprobación de V.E. seguro de que le he emprendido creyendo puede convenir al servicio de Dios y del Rey»s.

En su escrito, Aróstegui planteaba varias cuestiones. Ante todo la dificultad de poder saber con certeza la verdadera personalidad y las inclinaciones de los purpurados ya que «tiene en Roma la simulación y el artificio su asiento» y «los más de Papas son otros de lo que eran siendo Cardenales», y luego la imposibilidad de dar alguna norma sobre el posible desarrollo de un cónclave por la volubilidad de las circunstancias y por las diversas combinaciones de intereses que se ponían en juego. No olvidemos que en la mente de Aróstegui estaba presente el cónclave que eligió a Benedicto XIV en 1740 y que fue el más prolongado del siglo XVIII por su duración de más de seis meses ${ }^{6}$. Sobre los posibles problemas de conciencia que se pudieran plantear, adjuntó a su informe una Relación de lo que se hizo en la Junta que hicieron por mandado de S.M. Los Padres Confesores de S.M. y A. y el Padre Joseph de Acosta ${ }^{7}$. En este papel manuscrito se refería la constitución de una junta en junio de 1598 por orden de Felipe II -y pocos meses antes de su fallecimiento, que se produjo el 13 de septiembre siguiente- en la que participaron los Padres dominicos fr. Diego de Yepes, confesor del monarca, fr. Gaspar de Córdoba, confesor del príncipe heredero y el jesuita Padre José de Acosta, rector del Colegio de la Compañía de Jesús de Salamanca. Éstos formularon sus conclusiones en nueve puntos que se reducían a sugerir que se promoviese a la cátedra de San Pedro a aquel purpurado que fuese más util para el gobierno de la Iglesia universal ${ }^{8}$. De este modo, se libraban de escrúpulo los intereses

5. Aróstegui a Carvajal. Roma, 19 de marzo de 1750. A.H.N. Estado. Leg. 3406. n 8.

6. Sobre este cónclave, cf. PASTOR, L. Historia de los Papas. Vol. XXXV. Barcelona. (1937). pp. 7-25.

7. A.H.N. Estado. Leg. 3406. $n^{\circ}$ 8. Copia.

8. Tras consultar los papeles necesarios que fueron enviados por el duque de Sessa, embajador de Felipe II ante Clemente VIII, los Padres Yepes, Córdoba y Acosta resolvieron lo siguiente: «1 $1^{\circ}$. Puede S.M. lícita y santamente poner la mano en las elecciones de Summos Pontífices, procurando se elija el que conviene por las razones que se tocan en el memorial del Padre Acosta a que se remiten. $2^{\circ}$. Es lícito para 
políticos que el soberano había propugnado durante su vida y se concedía finalmente una respuesta favorable y tranquilizadora a la conciencia de Felipe II poco antes de expirar, quien había estado «firmemente persuadido (como todos los Austrias) de que lo que era bueno para su imperio era bueno para la universal Iglesia» ${ }^{9}$. No obstante, en el siglo XVIII, si bien las causas espirituales que hacían necesario tener un Papa adicto eran las mismas, en el orden temporal, como señalaba Aróstegui, las circuns-

el fin dicho usar de inclusiones nombrando los Cardenales que a S.M. le pareciere ser más dignos del Pontificado, y de exclusiones desechando los que tiene por indignos. $3^{\circ}$. En la inclusión o nombramiento se deve sobre todo mirar que el que se pide sea el que se entiende ha de ser más útil a la Iglesia de Dios. Porque entre los que se puede hacer elección, siempre se ha de prender el más digno, y quando se juzgase que el que es más amigo, no sería tan bueno para el govierno de la Iglesia, no es lícito de preferir el interés propio al común de la Christiandad. $4^{\circ}$. Quando de algún Cardenal se entiende que tendrá mejor correspondencia con el Rey, siendo por otra parte idóneo para el govierno universal, es lícito preferirle a otro igualmente digno, y generalmente mientras el mayor poder de la Christiandad y la mayor seguridad de la Fe y Religión Católica se halla en la Corona de España, como al presente por la gracia de Dios es notorio, aquél se puede tener por más idóneo para el Pontificado, que terna [sic] mayor correspondencia para el servicio de Dios con esta Corona como en lo demás tenga las partes convenientes de rectitud, prudenzia, valor y letras. $5^{\circ}$. En las exclusiones dévese mucho mirar que no sean excluidos por ligeras causas o sospechas, porque la exclusión que hace S.M. es eficaz de ordinario, por tener tanta parte en el Colegio de Cardenales que baste a quitar el Pontificado, y no tanta que baste a darla por sí sola, y de hacerse exclusiones por sospechas y causas no muy graves se siguen dos inconvenientes: uno de privar a hombres dignos y beneméritos de Dignidad tan grande que es gravísimo daño de la Iglesia; otro de hacerles enemigos perpetuos y declarados. $6^{\circ}$. Las causas que bastan a excluir son las que bastan a juzgarse por ineptos y indignos del Pontificado, de cuyo govierno se entiende que la Iglesia universal recivirá detrimento. Es también entenderse por claros indicios que serán contrarios a la Corona de España quando hay otros que se juzgan por igualmente dignos, cuya mejor correspondencia con el Rey Católico redunda en bien de la Iglesia, como está dicho. $7^{\circ}$. Para tener los Cardenales ganados y anigos, es lícito hacerles mesadas a ellos o a sus deudos, y darles pensiones y ofrecerles favor para sus pretensiones lícitas y honestas, más en tiempo de sede vacante quando ya se trata de elección no se deven usar tales medios de dadivas o promesas, porque entonces tienen olor de pacto implícito. $8^{\circ}$. Para que en negocio tan grave se proceda según Dios y razón es necesario que al embaxador y ministros se les advierta claramente de la sana y christiana intención del Rey Nuestro Señor, por la qual importará que aquella carta tan digna de Su Mag. la tengan y refresquen a su tiempo los embaxadores y que a los Cardenales confidentes que se les diga expresamente que en lo que se les pide por parte de S.M. no es su intención que hagan contra sus conziencias ni por seguir el dictamen de ellas S.M. no se tendrá por ofendido ni deservido, porque el mayor escrúpulo que en esta materia puede haver es con temores o dadivas impedir la libertad de los electores. $9^{\circ}$. Por quanto al tener mano S.M. en las elecciones de Papas es de tanta importancia para su reputación y para sus negocios; y es asímismo de grande utilidad a la Santa Iglesia usándose cristianamente, para que el Pontificado se dé a quien mejor ha de governar la Iglesia. Por tanto, dévese mucho mirar en tener verdaderas y enteras informaciones de las partes y méritos de los Cardenales; y tanto más quanto se ve por esperiencia que los embaxadores y ministros suelen aficionarse a unos y a disgustarse de otros, y sus informaciones son siempre del color que tienen sus ánimos, así que a ellos se les ha de advertir esta puntualidad que deven guardar y por otras vías procurarse S.M. certificar de lo que no fuere tan cierto. Ultimamente por experiencia larga se ha visto que Cardenales que se tenían por amigos, siendo Pontífices se han buelto contrarios, y al revés los que no parecían tan a propósito han salido mejores para la Corona de España, cuyo exemplo deseando otros antiguos vemos en Gregorio XIII, como al contrario Sixto V, porque en los grandes estados prevalece a todas otras amistades o enemistades pasadas la pretensión o interés presente; siendo esto así no sólo por razón de concienzia, sino también de estado se deve procurar la elección del Pontífice más pío y más prudente y valeroso, pues será cierto que haciendo S.M. la causa de Dios, hará Dios la de S.M. y qualesquiera otros respetos y consideraciones se deven posponer a ésta, de que en la silla de San Pedro suceda el que es más a propósito de la Iglesia de Christo». A.H.N. Estado. Leg. 3406. n 8. Copia.

9. DOMÍNGUEZ ORTIZ, A. «Regalismo y relaciones Iglesia-Estado en el siglo XVII» en GARCÍA-VILLOSLADA, R. (dir.) La Iglesia en la España de los siglos XVII y XVIII. Vol. IV de Historia de la Iglesia en España. Madrid (1979). p. 76. 
tancias habían cambiado y la geopolítica italiana era distinta. Fernando VI no tenía ninguna posesión en aquella península y si le movía algún interés temporal era como jefe de la casa borbónica hispana y por razón de sus hermanos, los infantes D. Carlos, rey de Nápoles y Sicilia, y D. Felipe, duque de Parma, Plasencia y Guastalla. Razones familiares que obligaban a la corona española a mantener a raya a los Habsburgo austríacos y a evitar por todos los medios diplomáticos la enemistad de la Santa Sede.

En un informe de esta naturaleza, el eficiente Aróstegui traía a colación dos importantes armas con las que contaba el monarca católico -al igual que los soberanos de Francia y Austria- para poder intrigar en un cónclave en un sentido favorable a sus intereses: esto es, la Exclusiva y la Inclusiva. Por lo que respecta a la primera, o lo que era lo mismo, las insinuaciones o las amenazas por medio de un derecho de veto adquirido en la práctica y utilizado contra un posible «papable» desafecto con posibilidades reales de poder ser designado, era un procedimiento odioso que solamente podía usarse una sola vez durante el desarrollo del cónclave. Es más, como las primeras candidaturas, según señalaba la experiencia, eran las que se tomaban menos en serio al principio de un cónclave, tales propuestas podían ser hábilmente empleadas por los distintos jefes de facción que movían los hilos dentro del Sacro Colegio a fin de obligar a una potencia católica a utilizar apresuradamente su veto y de este modo quedar desarmada. Pese a que la exclusiva fue reprobada por Pío IV (constitución In eligendis de 1562), Gregorio XV (constitución Aeterni Patris de 1621), Clemente XII (constitución Apostolatus officium de 1732) y por otros pontífices posteriores, este veto se mantuvo en la práctica y se empleó por última vez en el cónclave de 1903 en el cual fue elevado al solio el cardenal Giuseppe Sarto -San Pío X-. Este Papa, por medio de la constitución Commissum Nobis de 1904, fue quien puso fin a esta práctica secular. Volviendo al escrito de Aróstegui, éste diferenciaba dos modos de exclusiva: la tácita «en quanto en fuerza de las negociaciones y partidos se haga todo lo posible para que no tenga lugar la elección de alguno o algunos» y que era la más conveniente ya que se conseguían todas las ventajas sin necesidad de exponerse abiertamente; y la expresa «en quanto en nombre del Rey se haze saver solemnemente al Sacro Colegio que el tal Cardenal no es grato a S.M. y que así le da la esclusiva». En cuanto a la Inclusiva, venía a reducirse a un detenida selección del sujeto o sujetos más proporcionados desde el punto de vista de la diplomacia española para acceder al solio pontificio - lo cual se notificaba previamente al embajador en Roma y al purpurado que fuese el portavoz o «protector» en el cónclave de los intereses del monarca hispano- y a un riguroso examen de los cardenales con cuyos votos se podía contar por diversos medios, o bien por sobornos o bien por promesas. En los siglos anteriores había sido frecuente conceder pensiones a los purpurados italianos, pero a juicio de Aróstegui, las cosas tampoco eran lo que habían sido y «oy es cierto no ay ninguno de estos Cardenales pensionados», aunque la práctica todavía continuaría ${ }^{l 6}$.

10. A Benedicto XIV, siendo cardenal, se le concedió una importante pensión que finalmente no fue pagada. Una curiosa esquela dice así: «En el año 1730 tomó S.M. bajo su Real Protección y amparo a los Cardenales Lambertini y Acoramboni y mandó se diesen mil doblones de pensión anual a cada uno y para el caso de haver Cónclave mil escudos, en atención al amor y zelo con que se interesaron en quanto fue del Real servicio en el Conclave último en que fue electo el Papa Clemente XII. El Cardenal Bentivoglio acordó en el año 1732 esta gracia y se dio orden para que se les aprontase una anualidad de dicha pensión, con todo secreto, por mano del mismo Cardenal Bentivoglio, a cuio nombre y 
Por lo que respecta a los partidos que había dentro del Sacro Colegio, compuesto entonces por 65 purpurados (50 italianos, 3 españoles, 4 franceses, 5 alemanes y 3 portugueses), Aróstegui distinguía dos modos de clasificación: por un lado, la más simple, por antigüedad, en la que señalaba el «Colegio viejo», compuesto por los cardenales criaturas de los pontífices anteriores; y el «Colegio nuevo», integrado por los cardenales nombrados por el pontífice reinante, Benedicto XIV. Por otro, la más interesante, por la diversidad de los intereses en juego, Aróstegui diferenciaba tres facciones: la de los celantes, el grupo más numeroso, que sólo buscaban el bien de la Iglesia haciendo la elección de un buen Papa y cuya posible cabeza, a juicio de Aróstegui, pudiera ser el cardenal Aníbal Albani, sobrino de Clemente XI, secundado por su hermano Alejandro Albani, su sobrino Juan Francisco y el cardenal Mosca. La del cardenal Corsini, sobrino de Clemente XII, que podría tener una gran influencia por sus miembros y por manejarlo posiblemente desde dentro el cardenal Valenti, por aquel entonces Secretario de Estado de Benedicto XIV. El llamado partido benedictino, el del pontífice entonces reinante y por tanto con posibilidad de cubrir las vacantes, carecía de un cardenal nepote capaz de aglutinar a todas las criaturas de este Papa y éstos, en caso de cónclave, engrosarían las dos facciones anteriores. No obstante, como posible cabeza dirigente de los benedictinos, Aróstegui especulaba con el cardenal Sciarra Colonna. A estos bandos había que añadir los partidos de las coronas, dentro de los cuales España, Francia y Austria eran los que tenían el principal peso ya que gozaban del derecho de la exclusiva y su común unión era muy improbable.

En suma, como una visión panóramica de lo que era el Sacro Colegio a mediados del siglo XVIII, de su importancia -siempre a tener en cuenta- en las relaciones hispano-romanas y como claro testimonio de las ambiciones y las combinaciones sutiles que se podrían producir en un cónclave, creemos de interés este documento que publicamos a continuación. Hemos respetado la grafía original, si bien hemos suprimido las reduplicaciones y hemos actualizado la puntuación y la acentuación.

\section{A.H.N. ESTADO. LEG. 3406. $\mathrm{N}^{\circ} 8$ \\ DISCURSO SOBRE CONCLAVE}

Puede contarse por uno de los argumentos de nuestra Religión el cuidado e interés que han tomado en todos siglos los Príncipes Christianos en la elección del Romano Pontífice; pues a fuer de venerarle como cabeza del Reyno de Christo y común Padre, quisieran todos fuese el elegido el que les fuese más afecto. Creció esta idea quando en los tiempos inferiores se unió al poder espiritual de las Llaves el temporal de una gran parte de Italia. De aquí vemos en la Historia tantas solicitudes empleadas por los Príncipes y sus Ministros en Roma para promover al Pontificado a aquellos que creyeron ser sus amigos; y para apartar de esta Dignidad a los que juzgaron contrarios.

no al de los dichos Cardenales debían ir las letras, expresando convenía mucho tenerlos afectos y obligados por los reales intereses a causa de lo iminente [sic] que entonces era un futuro Cónclave por la indisposición que padecía el Papa. Y que no se dudaba continuarían el mismo amor y parcialidad a España que en lo pasado. Parece que el pago no debió de tener efecto, aunque sí la real protección. Porque en el año 1735 representó el cardenal Aquaviva que nada se les havía satisfecho sin embargo de las varias representaciones de Bentivoglio y que aunque los dos referidos Cardenales no se havían explicado jamás en este asunto, podían recelar que no eran ciertas las promesas de la Real protección». A.G.S. Estado. Leg. 4955. Cf. nuestro estudio Jesuitas y reformismo, op. cit., p. 65. n. 29. 
Estas solicitudes usadas con la moderación y rectitud de intención que pide materia tan sagrada e importante, pueden ser lícitas y aún laudables; pero se debe caminar con mucho tiento, pues a poco que se extravíe la intención a humanas reflexiones, es fácil se atropelle la línea de lo justo. Considerando lo delicado de este punto el Sr. Phelipe II hizo se examinase por hombres muy doctos así en Roma como en Madrid lo que podría o no hazer para incluir o excluir algunos Cardenales en el caso de un Cónclave; y no pudiendo yo decir más, ni aún tanto como dixeron hombres tan insignes, me remito a su Consulta que incluyo adjunta, con lo que se satisface a lo que pide la conciencia en esta materia, que en sustancia es, a que se solicite por los Príncipes el que se promueva a la Thiara aquel que, atendidas las circunstancias, será el más útil para el govierno de la Iglesia universal.

Pero como la citada Consulta no cierra la puerta a que se hagan las reflexiones que dicta la razón de Estado, compatibles con la conciencia, mientras que entre las insinuadas circunstancias admiten por una de las que dignifican a un Cardenal la inclinación al Rey y a la Corona de España; y al contrario, suponen por una justa causa para la exclusiva la desafición [sic] al Rey o al Reyno; de aquí procede que S.M. y su Ministro podrán usar las diligencias y medios justos ya para promover a unos, y ya para apartar a los otros del Pontificado; reduciéndose todos los puntos en esta materia a estos dos de la inclusa o exclusiva.

Para regularse éstos con acierto, se haze necesario hazer una justa descripción de los Cardenales que se consideran proporcionados para el Pontificado, que por esto se llaman comúnmente Papables, y para el mayor conocimiento unir la de los otros que no se hallan con esta proporción, como se hará en este Papel; pero antes se haze preciso para determinar los pasos y diligencias, el considerar los intereses que en el presente estado de cosas tenga la Corona de España en la elección de un nuevo Papa, pues según éstos fuesen mayores o menores se deberá según reglas de prudencia tratar este negocio con más o menos actividad y con más o menos indiferencia.

Los intereses de España en Roma unos son por razón al estado espiritual y eclesiástico; otros por razón al estado temporal y profano. En quanto a los primeros, es cierto que España se puede decir que pende más que otra Potencia de Roma, en quanto es el Reyno más privilegiado de la Iglesia, y en quanto por la disciplina eclesiástica que en él presentemente se observa, son más frequentes los recursos a Roma que de otro algún Reyno, así por la vía graciosa de dispensaciones, colaciones e indultos, como por la contenciosa de Pleytos.

Grande interés parece éste si se mira al uso de la dependencia, pero pesado bien, no es lo que parece. Los Privilegios que ha concedido Roma a los Reyes de España no es fácil que ningún Papa los derogue, los más son concedidos por causa onerosa y han pasado a contrato; los más son tan antiguos que más tienen de costumbre que de Privilegio, y sobre todo, no puede un Papa meditar en quitarlos, sin que le ocurra se quite a sí mismo y a su Corte aún mayores intereses. Razón por la qual, aún en tiempos muy agrios y de rotura, o no han venido a la derogación o si han llegado a intentarla como en nuestros tiempos la del privilegio de la Cruzada, luego han sobreseído en el golpe y, reconociéndole más perjudicial a sí que al Rey de España. Y si por la actual disciplina se halla España tan pendiente en los puntos de dispensaciones, colaciones y pleytos, sabe Roma que así lo estubo Francia en otro tiempo y que sin faltar a la Fe, antes arreglándose más a los cánones antiguos, se libertó de esta dependiencia 
y lo que hizo Francia lo puede hazer España con mejores fundamentos y sabe Roma que ha amagado diversas vezes el hazerlo, no satisfecha de sus quejas. Con que por lo que mira a los intereses eclesiásticos, guardados se están ellos si no quiere un Papa concitarse contra sí toda su Corte, temerosa de perecer, porque si un Papa no concediese gracias, indultos y colaciones a los Españoles, ni los admitiese en sus tribunales, que es caso quimérico, también le faltaría el dinero y a España no le faltaría modo de que el mismo Papa de valde la proveyese.

Síguense los intereses temporales, esto es, los que se derivan del Papa como Príncipe temporal en Italia. Mientras que el Rey de España poseyó en Italia los estados de Nápoles, Sicilia y Milán con la adjacencia de las Islas de Cerdeña y Córcega, se pudo decir verdaderamente que la España tenía un interés muy considerable en la elección de los Papas; pues la Historia nos haze ver quanto contribuyeron los que fueron parciales a la seguridad y acrecentamiento de dichos Estados; y al contrario, quanto turbaron y se perjudicaron los Papas que fueron contrarios, ya por sí solos, ya haziendo ligas con los enemigos de España; añadiéndose otra razón para mayor interés y es que Roma en aquel mismo tiempo tenía parte e influxo en los negocios y movimientos de los más Príncipes temporales, encadenándolos con tal destreza que como observa nuestro político Saavedra era Roma entonces la oficina de la Paz, o de la guerra en Europa. Pero no teniendo en estos tiempos la Corona de España por sí dominio alguno en Italia, y careciendo ya Roma de aquel influxo tan activo en las operaciones de los demás Príncipes, no se puede decir tenga el Rey de España por sí interés immediato temporal en que sea este Papa, antes que otro, y por lo mismo todas aquellas grandes diligencias, solicitud y cuidados que emplearon en este punto los Reyes en los tiempos pasados, no pueden servir de regla ni de exemplo que persuada para el presente.

Pero aunque el Rey no tenga por sí immediato interés, le tiene por razón de sus Serenísimos Hermanos, en quanto éstos poseen el Reyno de Nápoles y Sicilia y los Ducados de Parma, Plasencia y Guastala con los Alodiales de la Casa Farnese, y pretensiones a otros bienes, cuya manutención se gradúa interesante, a proporción del estrecho vínculo de la sangre y atendida la qualidad feudal de algunos de dichos Estados, la reciente posesión de sus dueños y la sospechosa vecindad de la casa de Austria, que aún los apetece, parece fuera muy conducente tener siempre el Papa amigo para su quieta conservación; y al contrario fuera de temer un Papa contrario, ya por sí, ya aliándose con la Casa de Austria, y otros Príncipes de Italia, aunque esto no fuese a la descubierta, sino como aquí se dice, sotto mano, para lo que Roma abunda tanto de industria como carece de fuerza.

Este es el interés, que se puede considerar tener el Rey para el caso de un Cónclave, sobre el primero de Rey Cathólico, en que se haga el Papa que más convenga para el bien de la Christiandad, y así se consideró por el Rey Padre Nuestro Señor (que santa gloria aya) en carta escrita de su Real orden por el Señor Don Sebastián de la Quadra al Cardenal Aquaviva en 9 de Febrero de 1739 en que será bien insertar aquí:

«Para poder responder en este asumpto instruyendo a V.Em. del ánimo positivo del Rey en materia de tanta gravedad y de cuyo acierto necesariamente ha de nacer un nuevo aumento, lustre y explendor a nuestra santa fe, ha sido preciso informar a S.M. con claridad y distinción de todas las reflexiones, noticias y discursos que expone V.Em. con su acostumbrado celo en la citada carta, para que con vista de todo pudiese 
S.M. encontrar mejor con los medios más adaptables al servicio de Dios y bien de su Monarquía. Enterado, pues, y deseando eficacísimamente concurrir a que el govierno universal de la Iglesia recaiga en sujeto en quien además de las apreciables prendas de virtud, prudencia y justicia que se requieren para ser verdaderamente Padre común, se descubra una experimentada inclinación acia los intereses y justos derechos de esta Corona, y del Rey de las dos Sicilias su Hijo; o a lo menos una absoluta y total imparcialidad, ha resuelto que V. Em., valiéndose de todos aquellos medios santos y justos que le dicte su prudencia y acreditada conducta, aplique vigorosamente los efectos de su Real protección para que sea promovido al Pontificado el Cardenal Ruffo, en defecto de éste el Cardenal Gotti, y quando éste no el Cardenal Cenci, porque éstos tres Purpurados son en quienes, según el detail de V.Em. se encuentra más bien el conjunto de circunstancias que S.M. desea para el logro del fin y santo celo que le guía.

Pero como es posible acaso que los constituyentes del futuro Cónclave no conspiren unánimes a la promoción de alguno de estos sujetos, o que alguna de las Potencias, dándoles la absoluta y explícita exclusiva los improporcione, y quite la aptitud, en tal caso quiere S. Magd. que teniendo V.Emª presente que los intereses del Rey de Nápoles, su Hijo, los considera S.Magd. como propios, se empeñe V.Ema ${ }^{\mathrm{a}}$. en que la elección recaiga en el sujeto que tubiere por más conveniente al bien universal de la Iglesia y a los intereses de Sus Magdes. sin perder V.Em. de vista a este fin las instrucciones que se le hubieren dado por la Corte de Nápoles».

Descubiertos los intereses y por éstos el fin que se debe llevar en las negociaciones o diligencias, se sigue ahora el hablar de éstas. Y haviendo de discurrir Christianamente como corresponde a materia tan sagrada, es cierto que los pasos que en esto se den deben ser muy honestos, pacíficos y prudentes, pues junto con la Religión, lo persuade así la razón. Si se tratase de dar un estado a uno que seguramente se savía su parcialidad en confronto de otro ciertamente enemigo, y se supiera que las diligencias havían de producir sin duda el efecto deseado, no será estraño que se practicase toda solicitud con el mayor fuego y empeño, pero aquí sucede todo lo contrario, por lo que se debe tratar esto con templanza y moderación creyendo que lo demás no sirve, por más que algunos o por ostentación de política o por hazer negocio quieran persuadir.

En primer lugar se trata de dar la graduación y preferencia entre muchos y a esto debe preceder el caracterizar los sujetos para incluir a unos y excluir a otros; y no es fácil decir quan falibles son los juicios que sobre esto se forman. Tiene en Roma la simulación y el artificio su asiento, y es sabido que los más que aspiran al Papado estudian de por vida el ocultar sus defectos y pasiones así en lo moral, como en lo político, o con su bella afectada apariencia, o con un cuidadoso retiro que impide el conocer su verdadero carácter. Tal finge quebrada salud, estando muy sano, por ser odiosos los largos Pontificados. Tal bajo capa de virtud y devoción encubre su ánimo estragado, porque al fin el vicio siempre es aborrecido. Tal haze el pusilánime, porque no gustan los Papas emprehendedores. Y tal, finalmente, se vende neutral en lo público, y parcial en secreto de algún Príncipe, procurando engañar con unas mismas frases a todos. ¡Véase que fácil será formar el carácter justo de estos Señores!

Pero quando la perspicacia de un Ministro fuese tal, que no obstante la simulación y el retiro penetrase el interno de ellos, formando de cada uno el verdadero concepto de su mérito y de su verdadera afición por su Príncipe; ¿quién podrá asegurar 
que llegando al Pontificado el electo, sea lo que era quando Cardenal? Ello es cosa experimentada, que los más de Papas son otros de lo que eran siendo Cardenales. Sea por una especial asistencia con que Dios dirige a lo que más conviene las operaciones de su Vicario en la Tierra, o sea porque con la nueva Dignidad se visten de nuevos pensamientos e intereses, o sea porque toda su acción la reducen a lo de sus Ministros y que según el influxo de éstos varían de aficiones. Como quiera que sea ello, es cierto que muchas Potencias se vieron burladas en sus oficios y esperanzas y en un Cardenal que creyeron muy amigo se encontraron un Papa muy contrario.

A estas incertidumbres se añade la del éxito en las negociaciones. Se ha de tratar con muchos de diversos intereses. Las convinaciones de éstos son infinitas y que las rige más el caso que la prudencia, por lo que se ve que rara vez sale Papa el que entra en Cónclave con voz de tal, y las más vezes sale el que menos se pensaba. Léanse los Cónclaves que andan escritos y se verán las pruebas de esto. En el pasado no tubo voz alguna el Papa presente casi hasta el punto de hazerse, y en la relación que hizo el Cardenal Aquaviva a la Corte de los Cardenales Papables se olvidó enteramente de nombrarle. Y aquí es de advertir que se engañan o son engañados los Príncipes quando les hazen creer que tales y tales convinaciones se hizieron por su contemplación y respeto. Lo seguro es que los partidos y cábalas se forman sobre el pie de las particulares aficiones y parcialidades privadas de los mismos Cardenales. Estas se arman como y quando les conviene del nombre de éste o el otro Príncipe, y después le hazen creer que su Partido ganó la elección y que el Papa es hechura suya, siendo en sustancia un juego de particulares amistades e intereses.

Por fin el manejo de un Cónclave es una cosa tan llena de casualidades que no se puede dar regla ni práctica segura, o bien se atiendan las conexiones de los electores, o bien las qualidades y méritos de los eligendos. Unos promueven al virtuoso, otros al Literato, otros al Político, y bajo de estos títulos especiosos, los más agencian su interés. Por lo común se haze un mérito de la vegez, para poner el Pontificado en depósito; y muchas vezes termina la elección de uno que no se piensa el sólo deseo de salir de un Cónclave dilatado. Y así fue en el antecedente siendo al cabo cierto que en medio de los regiros y artes de la prudencia se conoce en la elección del Romano Pontífice más que otra acción humana la asistencia de Dios para dar a su Iglesia la Cabeza que más convenga y que en ella especialísimamente se verifica lo de Sortes mittuntur in sinum, sed a Domino temperantur, quedando siempre burlados los artificios y solicitudes de los hombres del decreto de la Providencia; por lo que a considerar este punto como merece, me parece que los Príncipes Cathólicos debían contentarse con poner aquella solicitud que bastara a mostrar su respeto a la Santa Silla y deseo de que se eligiese el más digno; pues por lo demás (hablando políticamente) por más fructuoso y seguro tendría el tratar de ganar un Papa electo que no cazar la voluntad de tantos Cardenales al ayre.

No entiendo en esto condenar el cuidado y conducta que suelen tener las Cortes; sólo si pretendo que no tenga lugar la opinión de muchos que miran la elección del Papa como una intriga profana, y que acaloran a los Príncipes a oficios que no son de practicarse, y a creerse más intereses en esto del que verdaderamente ay, de lo que más de una vez han nacido empeños escandalosos sin más razón verdadera que el capricho de los Ministros. 
Quedando, pues, a que sólo se deben practicar aquellas diligencias que la razón y el uso ha permitido, éstas han de mirar a dos fines, el uno de la esclusiva de aquellos Cardenales que se reputen contrarios, y el otro de la inclusiva de los que se juzgan dignos y bien afectos. Quedando que ver lo que puede España a cerca del uno y del otro en el estado presente.

LA EXCLUSIVA. Hablando de la esclusiva, ésta puede ser de dos modos, o tácita en quanto en fuerza de las negociaciones y partidos se haga todo lo posible para que no tenga lugar la elección de alguno o algunos; o expresa en quanto en nombre del Rey se haze saver solemnemente al Sacro Colegio que el tal Cardenal no es grato a S.M. y que así le da la esclusiva. La primera se regula por los mismos principios que después se dirán para la inclusiva, y así sólo se discurrirá aquí de la segunda.

El derecho de la esclusiva que el uso ha dado a las tres Coronas del Imperio, España y Francia es un arma que en el cónclave las haze respetables, y a sus Ministros temibles. Ella sola basta sabiéndola manexar para hazerse el Ministro honor y tener algún influxo en la elección, pues por temor de ella todos los partidos buscarán su amistad y qualquiera que salga electo ha de ser con su consentimiento, lo que basta para acreditar ha tenido acción y parte en qualquiera elección. Esto es lo que obra el sólo temor de la esclusiva; y esto de conocido lo tendrá España en qualquiera situación, aún quando le falte partido activo para la inclusiva.

La duda grande está en si oi por oi ai alguno o algunos Cardenales contra quien corresponda en su caso dar efectivamente la esclusiva, no contentándose con sólo poner miedo con este arma, sino llegando con efecto a dispararla. Y para la resolución supongo dos cosas: la primera, que se debe evitar quanto sea dable el llegar a dar la esclusiva abierta, pues sobre que por no poder darse más que una vez, queda desarmado el que la da, es de suyo cosa odiosa y suele grangear enemigos. La segunda, que en esto no se habla de los Cardenales Nacionales ni Ministros, pues éstos, como se suele decir, llevan ya la exclusiva in ventre; y así sólo se ha de discurrir de los Cardenales Italianos Papables. Hablando, pues, de éstos es bien dificultoso resolver la duda propuesta, pues si la esclusiva ha de servir para apartar de la elección al que se reputa enemigo de la Corona, lo dicho arriva haze ver quan incierto es el juicio que se puede formar sobre la amistad o enemistad de estos Señores; y por otra parte es seguro que Cardenal enemigo de España como España no le contemplo, y creo no le aya.

Es verdad que muchos de estos Señores Cardenales Papables son notados de geniales austríacos, y que por tales si no son opuestos a España como España, lo son como dominada de la Casa de Borbón, como aliada de la Francia y en confronto de la Casa de Austria, y por estas mismas razones no pueden mirar bien los establecimientos de los Serenísimos Infantes Hermanos de S.M. y siendo (según mi entender) los intereses de éstos los únicos visibles que S.M. tiene en Italia, parece se debiera desear que no llegase al Papado ninguno de los sobredichos y que sobre ellos debiera recaer la esclusiva. Si esta pudiera darse a muchos a un tiempo, o si los Cardenales geniales austríacos se redugesen a uno o dos, la cosa tenía poco que discurrir; pero como la esclusiva es un tiro que no puede dispararse sino una sola vez, sobre uno, y por otra parte son tantos los Cardenales de este genio, pues por no sé que influxo esta afición se halla pegada aún en algunos, que tenían razón para lo contrario; de aquí es que este punto necesita meditarse. El examinar qual sea el más genial y más adicto a la Corte de Viena para que sobre éste recaiga la exclusiva, reputo un examen mui incierto y 
mui falible. Ninguno lo sabrá esto mejor que la misma Corte de Viena; y así a mí me parece que lo que havía que hazer en esto era observar atentamente así en Viena como aquí en qué Cardenal tenían puesta la mira para promoverle, y por quien se descubría el Cardenal Millini, que sin duda llevará el secreto por ser el Ministro de más confianza de la Emperatriz; y entonces, si el caso, y las circunstancias lo pidiesen, verá la Corte si se le deberá dar la exclusiva.

LA INCLUSIVA. Estamos en la segunda parte de la Inclusiva: esto es lo que puede hacer España en la presente situación para arrivar al Papato [sic] alguno de su devoción; y para esto se haze preciso examinar los Cardenales sobre cuyos votos puede contar. En los tiempos pasados era formidable el partido con que entrava en los cónclaves, pues además de los súbditos así españoles como italianos, tenía pensionados casi todos los demás Cardenales, y de un cónclave para otro se estudiava en irlos ganando con varios premios; pero, o sea la mutación de sistema de Europa que ha hecho a los Príncipes menos atentos a este punto como dixe al principio, o sea otra razón que yo no alcanzo, oy es cierto no ay ninguno de estos Cardenales pensionados, y así la cuenta se restringe a los súbditos. En este número atendida la unión de intereses, o por mejor decir, atendido que los intereses que se van a promover son los de las Cortes de Nápoles y Parma, parece debíamos contar en la calidad de súbditos Cardenales los Napolitanos y Parmesanos, y en estos términos entrávamos en el cónclave con tres Cardenales españoles que son el Sr. Infante D. Luis y los Cardenales Portocarrero y Mendoza; con seis Napolitanos que son los dos Rufos, Garrafa, Coscia, Espinelli y Orsini; y dos Parmesanos que son Alberoni y Landi.

Este es el número de Cardenales que por la dicha unión de Cortes e intereses se representan a primera vista favorables; pero para no engañarse y proceder preventivamente con más conocimiento, se debe considerar el defalco y debilidad que puede haver en este número. En primer lugar parece se debe descontar el Sr. Infante Cardenal pues su alto grado acaso hará dificultosa su venida a Roma y concurrencia con los demás Cardenales. La edad avanzada del Cardenal Mendoza confrontada con la robustez del Papa haze también muy incierta su asistencia para el caso que falte éste, y así de los Cardenales españoles sólo queda que contar el Cardenal Portocarrero por hallarse residente en Roma, y con algunos años menos que el Papa, aunque con menos robustez y éste es el estado más ventajoso de Cardenales españoles con que podremos entrar en el futuro cónclave, supuesto que este Papa no ha de hazer ya más creación de coronas ni se espera haga ningún Cardenal Nacional a no ser un raro accidente.

Por lo que mira a los Cardenales Napolitanos, siendo en mayor número, aún ay menos que contar, pues en primer lugar como que son Italianos y como el Rey de Nápoles no tiene nómina en la creación de coronas, éstos no se computan como Cardenales Nacionales ligados a sus cortes seculares, sino como Italianos libres y sólo atados a la corte de Roma; razón por la qual en el cónclave pasado tengo entendido que el Cardenal Aquaviva pudo contar poco sobre ellos, no obstante sus solicitudes y amenazas acia sus casas y parientes. Además de esto se deben descontar el Cardenal Ruffo, Decano del Sacro Colegio, ya por hallarse en edad decrépita de [...] años, ya porque aunque asistiera al cónclave, su genio fuerte a fuer de recto le hiziera incapaz de entrar en convinación y sólo siguiera la de los zelantes. El Cardenal Coscia se halla tan postrado e imóbil en cama años haze que promete poca duración y aunque durase se haze increíble su asistencia, la que hará falta, pues en el cónclave pasado oigo 
fue voto muy seguro. El Cardenal Garrafa es hombre de [...] años, su genio voluble le asegura poco, pero aún es menos seguro, quando se tratase de ir contra el Partido Austríaco. El Cardenal Spinelli es sujeto que por su edad y por sus prendas de piedad, doctrina y zelo se gradúa aquí proporcionado para el Papado. Esto no lo dexará de conocer el mismo, y este conocimiento le hará resistir todo quanto le pueda estorvar para la Tiara, como fuera el tomar partido mas que el de los zelantes, y no sé yo con qué impresiones se hallará su interior hazia la Corte de Nápoles de resulta del negocio del Santo Oficio, bien que por lo que oigo aquí le creo buen patriota y con amor a su Rey, y quando no se estime este rezelo, juzgo le debiéramos desear por Papa quando llegase el caso. El Cardenal Antonio Rufo, mientras viviese su tío el Cardenal Decano siguiera su voluntad, pero faltando creo era uno de los que se podían contar con probabilidad, pues el amor a su casa y sus parientes le haría seguir por temor la voluntad de su Corte, quando aya algún temor de su voluntad. El Cardenal Orsini se halla Protector de Nápoles y el haverle dado la Corte este carácter puede asegurarle, mientras que la Corte le haga todas las confianzas a que él se cree proporcionado por dicho empleo, pero quando no sea así porque su edad jubenil y su cortedad de talentos impidan el confiarle el secreto para el cónclave (como naturalmente sucederá) no ay mucho que fiar, pues es sujeto puntilloso y que le agita la ambición.

Restan los Cardenales Parmesanos. El Cardenal Alberoni se halla con [...] años y la debilidad correspondiente a edad tan avanzada, lo que desconfía se pueda lograr la seguridad que havía en su voto, manifestada muy bien en el cónclave pasado y fortificada ahora con la qualidad de súbdito del Sr. Infante. El Cardenal Landi de edad de [...] años le tengo por voto seguro y que pudiera ser útil su manejo en el cónclave, por ser sujeto de habilidad y que como hechura de este Papa pudiera tener influxo en sus concreaturas, pero el estado de salud, según oigo hablar, promete poca duración.

Este es el estado actual de fuerzas con que oy se halla la Casa de España, si se ofreciese en el día venir a un cónclave. Del mismo se colige el que podrá ser, tardando algunos años la elección de nuevo Papa siempre serán pocas fuerzas si se atiende el número de votos seguros, pero podrán ser mayores en llegando el caso según las convinaciones que entonces se hiziesen con otros partidos. En esto no se puede ahora fixar cosa alguna de pronóstico, pendiendo de mil casualidades que puede haver hasta que llegue el caso. $Y$ así la instrucción que se aya de reglar sobre esto habrá de ser sobre las últimas relaciones que embie el Ministro de Roma quando amenaze la vacante.

Lo único que oy se puede hazer es considerar los partidos que habrá provablemente en la futura elección. En los cónclaves que suceden a un largo Pontificado como es éste suele haver dos partidos, uno del Colegio nuevo en que entran las creaturas del último Papa, y otro del Colegio viejo en que se comprehenden las creaturas de los Papas antecesores; y siendo más fáciles de unir los primeros que los últimos, es lo regular que los del Colegio nuevo son los primeros que se proponen y todo el manejo de los del Colegio viejo está en unirse para excluir hasta que se proporciona el que quieren, o el que menos repugnan, como sucedió en el cónclave pasado, pero esta convinación la dificultó en el caso que se medita por la dificultosa unión de las creaturas de este Papa.

Otra división reputo más verificable en tres partidos, que son el de Zelantes, el del Cardenal Corsini y el de las creaturas de este Papa, que llamaremos Benedictino. El primero compuesto de los que, o por virtud o por política no manifiestan otro fin ni 
partido que el de hazer un buen Papa y resistir al que no juzgan tal. Este partido es natural sea en esta ocasión muy numeroso y que se ponga a la testa de él por capo-facción el Cardenal Aníbal Albani, como lo hizo en el cónclave pasado, pues acostumbrado a esta suerte de mancjo toda su vida ya que le faltan las creaturas de su tío Clemente XI seguirá este rumbo del zelo, apoyándose también en su hermano Alexandro Albani y en su sobrino Juan Francisco, en el Cardenal Mosca su pariente y algunos amigos.

El segundo partido de Corsini puede ser aún bastante fuerte por el número de creaturas de su tío Clemente XII y de este partido, aunque en lo exterior lleve la voz el Cardenal Corsini, el manexo interior y secreto será acaso del Cardenal Valenti.

El tercer partido Benedictino, compuesto de las creaturas de este Papa, si se atiende el número de éstos será el más fuerte y más haziendo el Papa los que ay vacantes, pero no quedando entre ellos Cardenal Nepote es muy dificultoso que tengan cabeza que los una, pues llegando el caso no querrán ceder ni sujetarse unos a otros; por lo que reputo lo más natural que divididos se vayan a engrosar los dos partidos de zelantes y de Corsini, y no estrañarse que sean éstos dos los que valanceen en el cónclave. Si alguno veo con señas de poder hazer de cabeza en el partido Benedictino es el Cardenal Sciarra Colonna, pues a su nacimiento junta bastante capacidad, fuego y genio de partido, pero siendo joven creo fueran pocos los sequaces.

Estos son los partidos que se pueden formar dentro del Sacro Colegio, pero ay otros fuera de él como son los de las coronas, cada una respectivamente con sus súbditos y amigos. En este número entran el Imperio, España, Francia, Nápoles, Portugal, Polonia y Cerdeña; pero por lo regular sólo se consideran poderosas por el derecho de la esclusiva las tres primeras. El unirse estas tres coronas, siendo tan encontrados sus intereses, es un caso no esperable, bien que por un efecto maravilloso de la providencia se vieron unidas en el cónclave pasado a favor del Cardenal Aldrovandi; lo más frequente es unirse dos de ellas, y traher consigo los Príncipes de comunes intereses. Quando la Casa de Austria dominava la España y con ella los estados de Flandes y de Italia era lo común ir los Españoles y Alemanes unidos en oposición al partido de la Francia; pero después que la España esta posehida de la Augusta Casa de Borbón en los quatro cónclaves que ha havido se ha caminado sobre el pie de ir unidos Españoles y Franceses contra el partido de los Alemanes. Si los discursos que se han hecho hasta [a]quí no van errados por falta de noticias interiores de las cortes, parece que esta unión es aún más necesaria en el estado presente, quanto siendo al parecer los únicos actuales intereses de la Corona de España en Italia los establecimientos de los dos hermanos de S.M. y siendo éstos poco bien vistos y embidiados de la Casa de Austria, sólo puede no serle sospechosa la unión para la elevación de un Príncipe en Italia, qual es el Papa con una Potencia que por ser de una misma Casa se mancomune en sostener estos intereses contra otra Potencia émula; y por esta razón, sin duda, el Rey Padre Nuestro Señor en la Instrucción para el cónclave pasado ordenó al Cardenal Aquaviva que caminase de acuerdo en todo con los Cardenales Franceses.

Esta unión es conveniente estando a los principios de política y de razón y si se procede en ella con buena fe es utilísima, pues por reglas naturales la España y Francia harán Papa a su gusto; pero aquí está la dificultad. Es menester que las dos Potencias miren con igualdad y recíproca inclinación el interés común, pues si la una quiere servirse de la otra para promover su interés, abandonando el de la compañera, no puede haver unión; por esto en la misma instrucción en carta de 23 de Febrero de 
1740 se le previno al Cardenal Aquaviva en los términos siguientes: «Que con los Cardenales Franceses deberá V.Ema . manifestar la mayor unión, pero con la cautela de seguir sólo su pensamiento quando recaiga en sujeto afecto, o a lo menos que no le contemple V.Emª ${ }^{2}$. opuesto a los intereses de S.M.».

Esta dificultad resta a vencerla a las dos cortes; pero vencida ésta queda la de los Ministros respectivos en Roma a quien se les comunican las intenciones; pues podrá suceder que en Madrid y en París se den con la buena fe las órdenes para la unión, y que los Ministros executores discuerden [sic] por sus diversos conceptos, y acaso por sus particulares oposiciones, siendo mucho de temer que hubiese algo de esto entre los Cardenales Aquaviva y Tencin en el cónclave pasado.

Por tanto convendrá que en llegando el caso las dos cortes se uniformen sobre los sujetos que se debían promover, y los que se debían excluir y no contentándose con embiar a los Ministros las órdenes generales de que andubiesen unidos, les especificasen los expresados sujetos. Así intentó nuestra Corte se executase en el cónclave pasado; pero haviendo hecho el Marqués de la Mina, nuestro embaxador, el oficio correspondiente con el Cardenal de Fleuri; nunca pudo conseguir se hiziese como se deseaba, y así en vez de ir unidos, todo fue desconfianza y quejas.

Es muy probable que el Ministerio de Francia no quiera seguir la conducta del Cardenal de Fleuri en esta parte, pues save la triste figura que por ella hizieron los Cardenales Franceses en el cónclave, no haviendo podido arrivar a ninguno de los suyos y debiendo al cabo abrazar el que quiso el Cardenal Aquaviva; y por otra parte la corte de París se hará cargo que si le es útil en el cónclave la unión a España con Francia, no le es menos a ésta con España, pues de otro modo no puede asegurar su intento y su interés que no es poco, ya por las materias de la Bulla Unigenitus y ya por la parte que le conviene tener con las materias eclesiásticas de Alemania.

También se puede y se debe pensar a la unión de los Cardenales Portugueses y Piamonteses, pero dependiendo la facilidad o dificultad de esta unión de principios y travazones para mí ocultos, y que sólo la Corte los tendrá presentes, no me detengo a discurrir sobre ella; pues tal podrá ser el estado de cosas que acaso contra lo que se ha dicho aún fuera posible y conveniente la unión con los Alemanes.

Otras convinaciones se forman con los partidos internos del mismo Sacro Colegio según las divisiones propuestas; pero a cerca de éstas es más dificultoso el dar ahora regla preventiva, pues la robustez del Papa, la decadencia de algunos Cardenales y las ocurrencias que no se pueden adivinar hazen incertísimos los pronósticos. No obstante diré lo que según el estado presente me parece más provable.

El Sacro Colegio se compone ahora de 65 Cardenales: 50 Italianos, 3 Españoles, 4 Franceses, 5 Alemanes y 3 Portugueses.

De los Italianos son los 12 Romanos, 2 del Estado Pontificio, 5 Napolitanos, 3 Venecianos, 3 Ginoveses, 5 Toscanos, 2 Placentinos, 5 del Estado de Milán y Mantua, 2 Saboyanos y 1 Modenés.

Creaturas de Clemente XI son 6, de Conti 1, de Orsini 6, de Corsini 18, de Lambertini 34.

Albani no puede por sí hazer formal partido, no pudiendo contar sobre sus criaturas, porque el Decano está decrépito y San Clemente cadente; los otros 4 son un Francés, un Portugués, un Tudesco y un Placentino, esto es Alberoni, que está decré- 
pito, y es poco amigo de Casa Albani; con que sólo puede contar sobre los dos Albani, Alexandro y Juan Francisco, sobre el Cardenal Mosca como Pariente y sobre el Cardenal Paulucci, antiguo suyo dependiente.

Conti no tendrá facción, siendo su única creatura el Cardenal Alexandro Albani, adicto a los intereses de la propria casa y dependiente de las cortes de Viena y de Turín por ser protector de ambas.

El Partido Orsini hará poquísima figura ya por falta de cabeza que los una, pues aunque ahora está el Cardenal Orsini, no es fácil se le sujeten; ya porque de los 6 que se compone, es menester descontar a Coscia por impedido, a Lercari por afecto de la corte de Turín y a Querini por su espíritu independiente.

Las creaturas de Corsini son 18. Se deben quitar de este número Mosca que reconoce su creación a la Casa Albani, nuestro Infante Cardenal, un Portugués, un Tudesco, y un Francés, con que quedan 13 y a éstos se debe añadir el Cardenal Bardi que reconoce el Capelo al Cardenal Corsini, de manera que se pueden contar 14 hechuras del Cardenal Corsini, si bien las ciertamente dependientes son Guadagni, D’Elci, Bicchi, Spínola, Valenti, Gentili y Rezónico.

Las creaturas de Lambertini son 34, pero quitados los Nacionales, esto es, el de Baviera, Portocarrero, Rochefoucauld, Soubise, Troyer, Atalaya, Delle Lanze, y además Juan Francisco Albani, que debe cuidar con su casa, y Millini, Ministro de Viena, quedan 24 y como esta facción está sin cabeza, es natural que algunos sigan al Cardenal Valenti, Primer Ministro de este Papa, y otros al Cardenal Sciarra, creatura mal satisfecha de este Pontificado. Con el Cardenal Valenti andarán todos los lombardos; esto es, Cavalchini, Barni, Landi, Tamburini, Besozzi, Mesmer y Pozzobone1li, y es provable sigan este partido Oddi, Doria, Gerónimo Colonna, Simonetti y Estuard, con lo que puede ser fuerte, de cerca de 12 votos y no es fácil pronosticar si le seguirán Tanara, Delfino y Antonio Ruffo.

Con Sciarra andarán fácilmente Orsini con los suyos, Lanti, Sacripante y Bolognetti. La fresca edad de Sciarra, su viveza y genio de partido, junto a considerarse como cabeza de la nobleza y partido Romano, haze creer que su facción será grande y será acaso aún mayor de lo que ahora se piensa, pues es fácil se alienten en ella todos los quejosos del Cardenal Valenti, los que ahora disimulan y, por tanto, no se conocen.

No será estraño que en el principio del cónclave no se vea el partido de los Zelantes, pero le formarán los accidentes. No ay duda que el que por ahora tiene más crédito de celante e inteligente es Spinelli, y a éste seguirá Doria, su íntimo amigo, y es natural que como éstos, se puede decir que para el efecto presente no tienen amigos, ni enemigos, ni son apoiados visiblemente a ninguna corona, sean los principales del partido Zelante en el caso que por su obrar libre y franco se opongan a las ideas de Valenti y de Sciarra.

Los Franceses sobre los quatro Nacionales Rohan y Tencin dificultosamente vendrán al cónclave. Tienen seguramente a Lanti, Monti y Riviera, aunque se puede contar poco sobre éste por su quebrada salud. Tendrán, además, a D'Elci y Crescenzi, que han sido Nuncios en Francia; y es posible siga el mismo partido el Cardenal Oddi, governado de su Primo Monseñor Banchieri, Thesorero. Este partido andará con felicidad en el cónclave si tubiese la dirección y secreto el Cardenal de la Rochefou- 
cauld, pues el concepto de su buena fe, su prudente advertencia, y el afecto que se ganó en esta Corte le adquirirá sequaces. No será así si tubiese la dirección el Cardenal de Tencin, pues su genio fogoso le ha dado pocos amigos y le precipita en la mejor ocasión, como se vio en el cónclave pasado.

Los Alemanes tienen muchos votos proprios. De cinco Nacionales vendrán a lo menos tres, a que se añaden Millini y Alexandro Albani, Paulucci y Passionei que hazen siete, y si alguna desavenencia entre Millini y Albani no lo estorba, unidos a éstos los dos votos de Casa Albani, y alguno de los quatro Milaneses, y cinco Toscanos podrán llegar cerca de 12 votos. De este partido es natural tenga la dirección Millini, el que aunque Romano y instruido bastantemente en estas materias, discurre más theórico que práctico y su genio adusto no le dará mucho séquito.

Esto es lo que preventivamente me ha parecido hazer presente, para que se pueda tomar con tiempo alguna luz, y con ella prevenir lo que se juzgase conveniente, dexando lo demás a la habilidad y dirección del que hubiese de tener el secreto para el cónclave; pues fuera en vano querer desde ahora figurar menudamente las convinaciones de los partidos y las intenciones de éstos quando según la volubilidad de las cosas humanas, por pocos meses que pasen de aquí al cónclave, es natural sucedan transformaciones que no se pueden preveer y así el querer hazer el Profeta político en esto sería perder el tiempo y confundir más que aclarar la luz que se va a dar. Lo más que se puede añadir a lo dicho es la particular noticia de los Cardenales que oy viven, lo que executaré por el orden de sus creaciones, deteniéndome algo más en aquellos que puedan tener alguna voz en el futuro cónclave.

\section{NOTICIA DE LOS CARDENALES QUE OI COMPONEN EL SACRO COLEGIO De Clemente XI}

Thomás Ruffo, Decano del Sacro Colegio, Napolitano de edad de 85 años, hombre de toda probidad, por quien nuestra corte estubo en primer lugar en el cónclave pasado. Su avanzada edad haze ya superfluo el discurrir de sus bellas qualidades para este asunto.

Aníbal Albani, del Estado Eclesiástico, de edad de 66 años, Protector de Polonia. Ha sido cabeza de facción con las criaturas de su tío Clemente XI en los cónclaves pasados y en el último lo fue de los Zelantes, hombre de travesura de intención y de genio faccionario y que ha tenido muchos enemigos. Ha caído de representación después que renunció el camarlengato; no obstante tendrá juego en el futuro cónclave con sus Parientes y amigos y entonces se espera minifieste [sic] su oposición con el Cardenal Valenti, por los sucesos de este Pontificado. Él, como todos los de su casa, se estiman parciales de la Corte de Viena.

Armando Gastón de Rohan, Francés de 74 años de edad. De este por Nacional no ocurre que decir. Su edad y el estado de su salud dificultan buelva a Roma.

Nuño de Acuña de Atayde, Portugués, de edad de 84 años, va por la regla del antecedente.

Julio Alberoni, Placentino, de edad de 84 años. Es sujeto de quien se tiene noticia en esa Corte. En los cónclaves pasados manifestó su inclinación a la casa de España; pero su edad haze no se pueda contar sobre su voto. 
Phelipe Thomás de Alsacia de Bussú de Chymai, Flamenco, de edad de 69 años, Arzobispo de Malinas, su calidad de Nacional me escusa hablar de él. Le tengo por uno de los votos más seguros a favor de la casa de Austria; bien aquí se cuenta por hombre mui zelante.

\section{De Benedicto XIII}

Pedro Luis Carraffa, Napolitano, de edad de 71 años, su nacimiento le hace estimable, pero su conducta y poco talento hazen que no se deba poner entre los Papables. Por esto y por su inclinación al partido austríaco podía la corte de Nápoles contar poco sobre su voto.

Nicolás Coscia, Napolitano, de edad de 66 años, bien conocido en el Mundo por su elevación en el Pontificado de Benedicto XIII y decadencia en el de Clemente XII haze su residencia en Nápoles reducido a una cama, lo que dificulta buelva a asistir a otro cónclave; siendo cierto que en el pasado estubo muy constante por nuestro partido.

Angel María Querini, del Orden de San Benito, Veneciano, de edad de 68 años, hombre de doctrina y dedicado a escrivir y estampar. En sus obras ha mostrado no el mayor juicio y bastante fuego, lo que le ha acarreado algunas oposiciones, y éstas juntas a la qualidad de Regular y Republiquista le obstarán para el Papado, bien que sea hombre de piedad y zelo, como lo manifiesta en su Obispado de Brescia, donde oi reside.

Nicolás María Lercari, Genovés, de edad de 73 años, fue promovido a la Púrpura con poca graduación por Benedicto XIII de quien fue Secretario de Estado, en cuyo empleo mostró un corto talento. Su poco concepto y el estar impedido de la gota haze que oy no cuente para nada y lo mismo será en cónclave; si ha mostrado alguna propensión por lo pasado a alguna Corona, ha sido a la Francia.

Francisco Borghese, Romano, de edad de 51 años. Su ilustre nacimiento y la Púrpura son las dos únicas circunstancias que en él se ven, pero tan desnudas que no se cree tenga voz alguna para el Pontificado. Si obrase por sí sólo, creo siguiera con gusto el partido de España y Nápoles, así por las señas que hasta ahora ha dado, como por mirar el bien de su casa Borghese, feudataria en el Reyno de Nápoles.

\section{De Inocencio XIII}

Alexandro Albani, del estado eclesiástico, hermano del Cardenal Aníbal, de edad de 56 años, Protector del Imperio y de Cerdeña, y que hasta el año pasado hizo de Ministro de la Reyna de Ungría; a estos títulos corresponde su inclinación y ésta la ha manifestado en el tiempo de la guerra con sobrada actividad y fuego. Esto mismo ha hecho que la Corte de Nápoles le gradúe por uno de sus más contrarios, lo que junto al genio austríaco de toda la Casa Albani haze conocer quales serán en el Cónclave sus oficios. Su conducta en parte le da poco concepto, pero algunas partidas populares le adquieren bastantes sequaces.

\section{De Clemente XII}

Vicente Bichi, Florentino, de edad de 80 años, conocido en el Mundo por las controversias que excitó su Capelo entre esta Corte y la de Portugal. Pasa oy aquí como si nada fuese, y su avanzada edad y achaques hazen superfluo hablar más de él. 
Antonio Xavier Gentili, Romano, de edad de 67 años, de humilde nacimiento, canonista curial, genio apacible, maneras agradables y eclesiásticas. Es uno de los Cardenales que oy cuentan más en las Congregaciones; tubo alguna voz para el Papado en el Cónclave pasado; es natural la tenga también en el siguiente. Serán muchos los que se opongan por reputarle hombre doble, artificioso e irresoluto. Su estudio y disimulo le da el concepto de indiferente para todas las Coronas. Por lo que toca a España, sólo ay que observar que haviendo sido Datario, será naturalmente promovedor de los derechos de Dataría y procurará sostener las prácticas de la misma.

Raniero D'Elci, Florentino, de edad de 78 años, fue Nuncio en Francia, donde sin duda le graduaron bien afecto, y de aquí el Partido de esta Corona unido al Cardenal Corsini hizo gran esfuerzo en el último Cónclave por arrivarle al Papado; no es natural suceda así en el siguiente por su avanzada edad. Es un buen eclesiástico, aunque de ningunas letras y le creo siempre adicto a la Francia.

Fr. Juan Antonio Guadagni, Carmelita Descalzo, Florentino, de edad de 74 años, salió joven de la Religión para un Obispado, y así fueron cortos sus estudios; pero es de una vida muy eclesiástica. Su tío Clemente XII le hizo Vicario de Roma, en cuyo empleo ha manifestado bastante zelo, pero igual inexperiencia y alguna extravagancia. Pudiera tener alguna voz para ser promovido con el ausilio de su Primo, el Cardenal Corsini, si las qualidades de Regular y Florentino que aquí son mal vistas, no lo impidiesen. Le tengo por sujeto indiferente para las Coronas.

Domingo Riviera, del estado eclesiástico, de edad de 77 años, hecho Cardenal por nómina del Rey Jacobo de Inglaterra; ha tenido séquito y concepto de hombre de cabeza, pero de un año a esta parte se quenta decadente por un ataque de Perlesía, por lo que no sirve hablar de él.

Juan Bautista Spínola, Genovés, de edad de 67 años, sujeto que por su vida eclesiástica, por el juicio y prendas que ha mostrado en los empleos que ha tenido, es reputado por uno de los más bien dispuestos para el Papado. El Cónclave pasado fue mucha la voz que tubo por algunos días, llevado del partido de Corsini; no creo hubiese otra razón para la repulsa que la odiosidad que tenía entonces este partido y la poca edad del candidato; y cesando ahora este motivo creo puede ser uno de los que más se arriven y su elección fuera bien vista y aplaudida. La qualidad de Ginovés podrá hazerle algún estorbo, pero la indiferencia que observa puede vencer este reparo. Le reputo más afecto que contrario a España.

Pompeo Aldrovandi del Estado Eclesiástico, de edad de 80 años, hombre bien conocido, no menos por su capacidad y letras que por sus contrastes con la fortuna, así en la Nunciatura de España, que le expuso a una degradación, como en el último Cónclave, en que viéndose por 30 días próximo a ser Papa, acreditó su constancia de ánimo contentándose con quedar Datario, de donde también fue removido. Sus desgracias no le disminuyeron el concepto de docto y advertido, pero lo descubrieron más el de artificioso e interesado. En el retiro de su Obispado de Montefiascon se esfuerza a pensar oy como antes, pero sus muchos años burlan ya estos esfuerzos. Por un raro caso tubo en el cónclave pasado la protección de las tres Coronas principales, pero este caso es quimera que se repita, y con más luz se cree que su interior sea de la Corte de Viena. 
Joseph Spinelli, Napolitano, de edad de 54 años, Arzobispo de Nápoles donde reside. Su ilustre nacimiento, junto a su talento y manera de vida eclesiástica le haze uno de los Cardenales más respetados y que el público le mira con disposición para el Papado. Es estimado zelante por las máximas eclesiásticas y su zelo por la immunidad eclesiástica, el que ha manifestado bastante en los últimos debates y quentos del Santo Oficio. En Roma se alaba en todo su conducta en estos lances. En Nápoles, sin hablar mal de él, le notan de alguna imprudencia, demasiado rigor y poca sinceridad en ellos. Como esta diferencia de juicios es entre las partes contendientes, se debería mirar la justicia de la causa y el sentir de los desinteresados. Él de cierto ama a su Rey y hasta estos quentos logró su gracia. Oy aparece no estar en ella; puédese dudar si en esto tiene más parte la política y razón de estado que el dictamen interno del Rey. Cierto es que de los Cardenales súbditos, ninguno pudiera servir más que él en un cónclave, ni otro alguno se halla con la proporción que él para la tiara. El pensar o no pensar a él penderá de la voluntad de S.M.N. Las apariencias son de que oy en Nápoles no se piensa a este caso; quando otras razones ocultas y superiores no lo impidan, parece fuera bueno que se le empezase a tratar con esta reflexión.

Thomás de Almeyda, Portugués, de edad de 78 años, por Nacional y viejo no ocurre hablar de él.

Joseph Domingo Lambergh, Tudesco, edad 69 años, tiene fama de un bonísimo eclesiástico.

Carlos Rezzonico, Veneciano, de edad de 55 años, pasó a la Púrpura del Auditorato [sic] de Rota por su República. Es tenido por de bastante doctrina y cumple muy bien las obligaciones de Prelado en Padua, donde reside. Puede ser uno de los que tengan voz para el Papado, si no le estorva lo republiquista.

Domingo Passionei del Estado Eclesiástico, de edad de 66 años, corrió las Nunciaturas de Suizos y Viena y oi es Secretario de Breves. Se precia de erudito con el haver juntado una gran Librería; de verídico con hablar tempestoso, de eclesiástico con retirarse en las vacantes a los Monjes Camandulenses. El público le mira con concepto de poco juicioso, violento y algo extravagante. Su afición por la Casa de Austria es muy descubierta. No creo tenga voz para el Papado, sin embargo de su amistad y conexión con los Albanis.

Silvio Valenti Gonzaga, Mantuano, de 58 años de edad, Nuncio en Flandes y en España, y ahora Secretario de Estado. Hombre político y de cabeza, y a quien la fortuna, de muy pobres principios ha elevado y favorecido sin intermisión. Su genio festivo y despejado le ha abierto la puerta del favor en todas partes; con el que aquí goza del Papa es el dueño del Estado. De aquí le nace la embidia y oposición de muchos y en especial de la Casa Albani. Esto le indispone para el Papado, y aún le pudiera traher alguna persecución en el caso de la vacante; pero los empleos con que queda, el número de hechuras y su habilidad, no sólo le harán respetable, sino que será uno de los más poderosos en el cónclave y el Director de la facción de Corsini. En su interior no lo creo parcial de ninguna Corona, y si tiene alguna afición es por Francia y España. En lo exterior ha sido así reputado hasta ahora y ha tenido la odiosidad y aún persecución de la Corte de Viena; pero después que nuestras armas no han tenido en Italia la fortuna que se esperaba, y su Casa de Mantua queda súbdita de la Reyna de Ungría, se le nota huie las ocasiones de agriar la Corte de Viena y abraza las de suavi- 
zarla. Así ha sucedido en algunos negocios de Germania, en los actuales de Toscana y ya tiene la prenda de tener su sobrino mayor con oficio en el Palacio Imperial. Todo esto lo haze manteniendo en lo posible el trato y lenguaje de amistad con nosotros y los Franceses, y no se descuida en mantener sus amistades en Nápoles, como quien piensa a tener Protectores contra sus émulos en el caso de la vacante.

Pedro Guerin de Tencín, Francés, de edad de 68 años, por Nacional y porque nuestra Corte estará de él más informada que yo, no me ocurre que decir, sino que aquí es reputado hombre fogoso, que en el cónclave pasado tubo el secreto de la Francia y que entonces se agrió mucho con el Cardenal Aquaviva. Ama el tratar las cosas de Roma, donde mantiene menuda correspondiencia [sic]. Si bolviese a cónclave será dudoso si tendrá él el Secreto o el Cardenal de la Rochefoucauld.

Nerio María Corsini, Florentino, de edad de 63 años, por Nepote de Clemente XII llegó sin letras algunas al Cardenalato y a tener el mando en aquel Pontificado con el qual adquirió alguna experiencia en los negocios de esta Corte, por su mediano talento y maneras poco obligantes no ha sido el más feliz en ellos. El gran número de hechuras de su tío le hizo respetable en el cónclave último. Oy le quedan aún bastantes para ser atendido. Como es hombre de buen corazón y limosnero, no fuera estraño que tubiera alguna voz para el Papado. La Corte de Francia lo ha tenido y tiene por su amigo, la de Portugal lo mismo, siendo aquí su Protector, y con la de Nápoles tiene la conexión de estar allí sirviendo el Príncipe Corsini su hermano. Si llegara a la tiara adoptara las máximas e inclinación de sus Ministros.

Agapito Mosca, del Estado Eclesiástico, de edad de 70 años, hombre sin algunas letras ni concepto, pasa por buen eclesiástico a fuer de retirado. Si dominase la máxima que en algunos cónclaves ha regido de hazer un Papa buen hombre, con la expectativa de governarle los Ministros, pudiera ser promovido y tubiera asistencia del partido de casa Albani por ser su Pariente; siendo esta circunstancia la que le dio el capelo. Por haver hecho en él la restitución Clemente XII le tengo por indiferente para las Coronas.

El Serenísimo Sr. Infante Cardenal D. Luis. Mi respeto no me permite más que poner su nombre en este catálogo, venerando yo sobre todos las altas prendas y circunstancias de S.A.

Carlos María Sagripante, Romano, de edad de 59 años. Es uno de los Cardenales de más concepto por su doctrina, capacidad y juicio; oy no suena mucho por no estar incluido con los que están en el manejo; pero tengo por sin duda que en el futuro cónclave sea uno de los que tengan más voz y más manejo. En el antecedente se portó muy bien, siguiendo con fineza al Cardenal Aquaviva y aún he oído a algunos fuese quien a éste le diese la acertada dirección. Guarda oy una exacta indiferencia, pero siempre creo nos sería favorable.

\section{De Benedicto XIV}

Juan Theodoro de Baviera, de edad de 45 años. Las grandes circunstancias de este Señor hazen superfluo hablar de él para este asunto.

Joachin Fernando Portocarrero, español, de edad de 67 años, Protector y Ministro de España en Roma por cuyas circunstancias serán sin duda bien conocidas en la Corte sus ideas y por esto es en vano que yo me ponga ahora a adivinarlas. 
Camilo Paulucci, del estado eclesiástico, de edad de 56 años, corrió las Nunciaturas y la última que tubo fue en Polonia, donde hallándose al tiempo de la elección del Rey se mostró muy parcial del actual y contrario a Stanislao, de donde se le siguió algún atraso en el capelo y oposición de la Francia; y en esto mismo contrajo su afición a la Corte de Viena, donde oigo fue muy bien tratado. Oy es legado de Ferrara donde reside con poco afecto de aquellos naturales por algunas providencias de su govierno; por otra parte es hombre de advertencia, juicio y buenos modales, por lo que será uno de los que tengan voz en el cónclave.

Carlos Alberto Guidobono Cavalchini, nacido en Tortona, súbdito del Rey de Cerdeña, de edad de 65 años, ha hecho sus Prelaturas en esta corte hasta la Secretaría del Concilio, de donde fue promovido. Repútase un competente canonista curial. Su manera obscura y equívoca en el explicarse dificulta el juicio de su interior. Sin embargo es tenido por hombre advertido, complaciente y artificioso y que en su conducta manifiesta pensar al Papado. Contándose entre los Lombardos como Tortonés y siendo éstos muchos con el partido del Rey de Cerdeña, de quien es súbdito, pudiera abanzarse. Pero esto mismo junto a su ninguna afición a la casa de Borbón, puede ocasionarle una fuerte oposición.

Juan Bautista Barni del Estado de Milán, de edad de 72 años. No me detengo en su descripción, pues haziendo poco tiempo que estubo Nuncio en nuestra Corte se conocerá en ella bien su carácter. Por lo que aquí toca, es cierto que su bondad le ha grangeado el concepto favorable que suele estimarse para ser Papa y su conducta tan indiferente que le caracteriza de imparcial, sin embargo de ser súbdito de la Reyna de Ungría. Por otra parte los Lombardos y sus concriaturas se inclinarán más a él que al antecedente.

Jacomo Oddi del estado eclesiástico, de edad de 69 años, siguió la carrera de Nunciaturas y oy es legado de la Romania donde reside. Su corto concepto le hará poco atendido en el cónclave.

Federico Marcelo Lanti, Romano, de edad de 65 años, siguió la carrera de Goviernos en que tubo más concepto que el que ahora logra en Roma. Sin embargo, tiénele mediano por lo que mira a su natural y su conducta, ya que sus letras son ningunas. Si llegase a hablarse de él en el cónclave, recelo tenga oposición y aún esclusiva del partido austríaco, por computarse todo Francés, ya por ser su Madre de esta Nación, ya por tener dos Abadías en Francia, y ya por haver sido siempre protegido de esta Corona, a la que manifiesta descubiertamente su inclinación.

Marcelo Crescentii, Romano, de edad de 54 años, Arzobispo de Ferrara, donde oy reside. Hizo la carrera de Nunciaturas, finalmente en la de Francia. El ser de una casa de las más antiguas Romanas junto a una dulce índole, haze esperar sea uno de los que corran con más voz en el cónclave. Juzgo que en el tiempo de su Nunciatura en París contrajese alguna parcialidad por aquella corte; pues observo que los Franceses miran con amor a él y a su casa.

Jorge Doria, Ginovés, edad de 40 años. Legado de Bolonia donde reside, siguió la carrera de Goviernos y el deseo del presente Papa de hazerlo Cardenal le destinó Nuncio a la Dieta de Francfort, en que fue elegido Carlos VII. Este mérito le anticipó la fortuna del capelo. Creo esté nuestra Corte instruida de su carácter desde el tiempo de la Dieta. Esto y no haverle tratado, me impide hazer de él una exacta descripción. 
En Bolonia ha [ma]nifestado un natural vivo y emprehendedor con máximas de celante. Su poca edad le inproporciona al grado de papable. Su inclinación a la Corte de Viena parece será ninguna, si se atiende a que ésta en la última guerra le sequestró una Abadía en el Estado de Milán. Nuestros Colegiales españoles de Bolonia han tenido con él algún enquentro, de lo que ya está informada la Corte; pero esto no ha sido especialidad, haviendo sucedido lo mismo a otros.

Francisco Landi, Placentino, edad de 65 años. El favor que logró años pasados en nuestra Corte por medio del Marqués Scotti, coadiubado [sic] del Cardenal Valenti le hizo llegar con poco tiempo de Prelatura inferior al capelo. Oy es Arzobispo de Benevento donde reside; bien que por motivo de su gastada salud dispone el venir a Roma y aún se dice a renunciar el Arzobispado. Tiene el crédito de muy capaz y político, pero como al mismo tiempo es tenido por hombre muy suyo y que las amistades sólo las aprecia en quanto le sirven. Es de dudar mucho tenga parciales que le arrimen al Papado. Si retiene la memoria del principio de su fortuna, deberá tener inclinación a España, y por la calidad de súbdito tiene obligación a profesarla a los intere- ses del Sr. Infante D. Phelipe.

Joseph Pozzobonelli, Milanés, de edad de 52 años, de Canónigo de Milán por su desbarro de fortuna ascendió al Cardenalato, junto con el Arzobispado de la misma Iglesia donde oi reside. Su concepto siempre es el de haver hecho una fortuna desigual a su mérito, y aquí es poco conocida su Persona. Con todo oigo cumple muy bien las partes de Prelado. En quanto a su inclinación y partido se debe regular como los demás milaneses.

Francisco Ricci, Romano, edad 69 años. Su proporción y mérito para el capello fue la de hallarse Governador de Roma, pues fuera de esto no es hombre de letras, ni de particular talento. Sin embargo, es hombre de bonísima intención, suave, y reputado por muy buen eclesiástico, y juntando a estas partidas la de su docilidad, su indiferencia para con las Coronas y la qualidad de Romano puede esperarse corra en el cónclave con buena suerte.

Antonio Ruffo, Napolitano, edad de 61 años. Su nacimiento y los empleos más que el mérito intrínseco le arrivaron al capelo como al antecedente. Es de aquellos que se caracterizan con el título de buenos hombres. Su poca salud y su casi total inhabilidad corporal ocasionada de la gota, le indisponen para el Papado. Su voto será a la devoción de la Corte de Nápoles, pues el amor a su casa y numerosa familia en el Reyno le hará siempre dependiente; sin embargo que pueda tener alguna queja, por no havérsele dado la Protección de aquella Corona.

Phelipe María Monti, Boloñés, de edad de 73 años, de la Secretaría de Propaganda pasó al capelo sin particular mérito. Tiene aquel concepto que gana el ser hombre retirado, y dedicado a estudio de bellas letras, de las que ha juntado una rica Librería. Su natural es obscuro y poco agradable, por lo que tendrá muy poca voz para el Papado, y aún le indispondrá más su descubierta parcialidad a la Francia, contrahida por el ventajoso establecimiento en aquel Reyno de su hermano y su sobrino.

Fortunato Tamburini, Modenés, del Orden de San Benito, edad 65 años. La fortuna le arrivó al cardenalato, pues su theología es muy mediana, igual talento y su explicación obscura. Con todo, la falta que ay oi de Theólogos en el S. Colegio haze que se le emplee como si fuera excelente. Su porte modesto y su retiro y trato religio- 
so le adquieren en lo moral un buen concepto. La qualidad de Regular y la opinión de duro y tenaz en sus sentimientos le harán tener poca voz para el Papado, su inclinación será igual acia las Coronas y su voto andará con el partido de los zelantes.

Joachin Besozzi, Milanés, del orden de S. Bernardo. Edad 69 años. Está casi en la línea del antecedente, bien que su Theología es algo más estimada, o sea porque en la verdad es mayor, o sea porque su talento más claro y sus modales suaves y agradables la hazen comparecer más. El porte y trato que profesa le acreditan buen Religioso y bien visto, de modo que si no le estorba la circunstancia de Regular puede considerarse de los más proporcionados para la Thiara. En quanto a su afición corre por la regla de los demás Lombardos, y seguirá el partido de éstos o el de los zelantes.

Alvaro de Mendoza, español, edad de 77 años, sus savidas circunstancias hazen superfluo el discurrir aquí de su Persona.

Daniel Delfino, Veneciano, edad 63 años, Patriarca de Aquileya, cuya Dignidad y nacimiento le ganaron la nómina de su República para el capelo; pues por otra parte es hombre pobre de espíritu y ciencia, bien que muy buen eclesiástico, con que es superfluo hablar más de él.

Raniero Simonetti. Del Estado Pontificio, edad 73 años, fue Nuncio en Nápoles y después Governador de Roma, con lo que se hizo mérito extrínseco para el capelo; en el intrínseco no tiene cosa especial, pues le faltan las Letras y su capacidad es mediana. Está si reputado por buen eclesiástico y genio blando. Su inclinación se cree sea por el partido Austríaco y no dexará de tener voz en el cónclave.

Federico Gerónimo de la Rochefoucauld, Francés, edad 46 años, hombre de todas prendas. En el tiempo que estubo aquí embajador las manifestó en un grado que le hizieron universalmente bien quisto y respetado, juntando lo esplendoroso de Señor y Cavallero con lo morigerado de Eclesiástico, y lo advertido y prudente de $\mathrm{Mi}$ nistro. Esto haze creer que en el futuro cónclave tenga el secreto de su corte y siendo así, se puede asegurar que sin perder de vista las intenciones e intereses de su corte, atenderá a lo más honesto y conveniente. Y creo que por lo relativo a España, no sólo no tenga preocupación contraria, sino que mostrará inclinación en quanto se le permitan sus instrucciones. El, como quiera, hará un gran papel en el cónclave.

Armando de Rohan de Soubize, Francés, de edad de 31 años, junta a su ilustre nacimiento una grande aplicación al estudio, la que le ha debilitado la salud a estado de temer dure poco y como Nacional no ocurre hablar más de él.

Fernando Julio Troyer, Tudesco, edad 49 años, reside en su Obispado de Olmitz en Moravia y no siendo conocido aquí, no ocurre que decir más de él, siendo Nacional.

Juan Bautista Mesmer, Milanés, edad 77 años. El empleo en que se hallava de Thesorero le arrivó al cardenalato. Es bastante versado en la jurisprudencia de estos tribunales y hombre de buen fondo, bien que en el trato manifiesta dureza. No le considero tenga voz en el cónclave y en lo demás correrá la regla de los demás Lombardos.

Joseph Manuel de Atalaya, Portugués, edad 62 años, por ser Nacional no ocurre cosa particular que decir.

Mario Millini, Romano, edad 71 años. De Auditor de Rota fue hecho Cardenal a nómina de la Reyna de Ungría. Desde su juventud ha tenido con la Corte de Viena confidente correspondencia; la que en el Pontificado de Clemente XI le desgració con 
la Corte de Roma, recelosa de havérsele por su causa malogrado algunas negociaciones. Esta impresión le frutó las mayores diligencias para que el presente Papa le nombrase Cardenal, de donde la Corte de Viena tomó el empeño de hazerle por su nómina, y después le ha nombrado su Ministro. Estos hechos hacen ver quan fuerte sea su adhesión al partido Austríaco, y quan provable que tenga su secreto en el futuro cónclave. La representación que hará en él si se atiende al número de Cardenales adictos a este partido parece será grande. Su dirección no faltará por la parte de capacidad y conocimiento; pero su genio ígneo y preocupado de la pasión a la casa de Austria y odiosidad a la Francia, y sus máximas de hombre solitario e hipocondríaco prometen poco efecto a sus intentos. Por lo tocante a España es de los que alaban y estiman lo que fue y están mal quistos con lo que es, creyendo la Nación otra, después que faltó de ella la Casa de Austria y de aquí nuestras modestas pretensiones en materias eclesiásticas las lamenta como una decadencia e infección de las máximas francesas.

Carlo Victorio Amadeo de le Lanze, Piamontés, edad 36 años, en el tiempo que ha estado en Roma ha mostrado muy buena capacidad, bastante doctrina y una conducta muy eclesiástica. No dexará de hazer una buena figura en el futuro cónclave, teniendo naturalmente el secreto de la Corte de Turín, cuyo partido no será corto, ya por los Cardenales súbditos, ya por los bien afectos; pues el Rey de Cerdeña save cultivar a Roma, como que el estado de esta Corte en Italia puede influir mucho a sus intereses.

Enrique Benito María Clemente Stuard, Duque de York, edad 23 años, sus altas circunstancias son bien sabidas. Su vocación al estado eclesiástico se ha verificado con su admirable modo de vida, el que tanto como su sangre le haze en esta Corte amado y respetable. Sus deseos en el futuro cónclave se enderezarán a los más justo sin profesar adicción descubierta a partido alguno; bien que en términos iguales creo difiniera a lo que la España deseara, pues tengo por cierta su inclinación movida de gratitud y de su buen concepto, ayudando a esto su deferencia a Monseñor Ley, su Maestro de Cámara, natural de Cádiz.

Mario Bolognetti, Romano, edad 57 años. Por hallarse thesorero fue hecho Cardenal. Ni las letras, ni el talento, ni el porte le han dado concepto y sólo le haze estimable el ser de un buen corazón. No se cree tenga voz alguna en el cónclave y para su voto no se le descubre otra conexión que la del Cardenal Sciarra Colonna, siendo para las Coronas indiferente.

Gerónimo Colonna, Romano, edad 40 años, su nacimiento en la casa del condestable le ha arrivado a la Púrpura y al cariño del presente Papa, de quien es Mayordomo. A fuer de su natural dado a sus pequeños divertimentos, no disfruta su privanza y vive lexos de todo lo que es negocio. Fáltale además la doctrina e inteligencia, con lo que haze una grande inútil figura. Los partidos de las Coronas los mirara con un frío despego; algo de inclinación ha manifestado al Austríaco, pero prevalecerá en el caso la reflexión de estar los estados de su hermano en el Reyno de Nápoles; y no teniendo voz alguna para Papa, será muy dudoso donde arrimará su voto. Siendo lo más natural que vaya con algunos de sus concriaturas jóvenes.

Próspero Colonna de Sciarra, Romano, edad 41 años, con igual nacimiento, patria, edad y dignidad, es muy diverso del antecedente. Su casa, aunque Colonna, es 
émula de la del Condestable. Su capacidad es clara y despejada, su porte señoril y fastoso. Su genio activo y ardiente. Estudia y ama el comparecer y el poder y en su modo se haze temer. Por fin tiene las partidas de capofacción [sic] y oi por oi es el que más haze figura de tal, siendo de creer que le sigan las más de las criaturas de este Papa. Y teniendo enemistad con el Cardenal Valenti, le seguirán los contrarios de éste, que son algunos. Le contemplo indiferente para las Coronas, pero la que quisiese prevalecer en el cónclave será menester haga mucha cuenta de este Purpurado; bien que reputo dificultoso asegurarle, pues le determinará más el odio que el amor.

Alexandro Tanara, Boloñés, edad 68 años, de Auditor de Rota fue hecho Cardenal. Ni sus Letras ni su talento, ni su porte le han dado particular reputación; pero logra la de no ser hombre perjudicial, ser suave y dócil, con que no se puede excluir del grado de los Papables. Su inclinación a la Casa de Austria es tan inocente como grande y descubierta; no se cree pase de una pura genialidad, sin oposición de afecto a las demás Coronas.

Gerónimo Bardi, Florentino, edad 63 años. Se halla Cardenal sólo porque llegó a ser Thesorero. Nada tiene que le haga notable; pero el concepto de buen hombre le tiene tan sentado, que puede esperar se hable de él queriendo hazer un Papa sin inconveniente. Es indiferente a las Coronas, y su voto andará o con las criaturas de este Papa o con el Cardenal Corsini, su paisano y amigo.

Domingo Orsini, Napolitano, edad 29 años. Como sobrino de Benedicto XIII le restituyó el Papa presente el capelo, estando recién viudo. La posible falta de sucesión en su Casa le mantiene aún sin orden sacro. Su estado antecedente dice su poca institución y letras. Su capacidad es limitada, su porte decente, de modo que pasa sin especial nota, si ya no es alguna ambición por ingerirse en negocios, la que ha mostrado aquí y en la Corte de Nápoles de la que ha logrado el ser nombrado Protector; con cuyo título es dable que aya mudado algo la afición al partido Austríaco, de que antes era notado. Será natural piense tener el secreto de aquella Corte en el cónclave, pero es muy difícil que la Corte tenga este pensamiento, no tanto por desconfianza del afecto, como del buen efecto.

Juan Francisco Albani, del estado eclesiástico, de edad 28 años, fue hecho Cardenal por nómina del Rey de Polonia. Su poca edad y el retiro en que se ha criado impide hazer juicio cabal de él; pero la escuela del Cardenal Aníbal, su tío, en que se ha educado, y las potencias claras que manifiesta, juntas a una advertencia juiciosa, hacen esperar sea un Cardenal de quenta y que con sus conexiones pueda y sepa llevar adelante el nombre y poder de la facción Albani, que tanto tiempo haze ha estado en consideración. Su inclinación en el estado presente se debe regular por la de sus tíos. 